\title{
7 he Romanian Journal for Baltic and Nordic Studies at its tenth anniversary: articles, reviews, notes, interviews, events
}

Alexandra Airinei, Al.I. Cuza University of Iasi

- Contributions:

- "Pre-Christian Scandinavian royalty. From the legendary kings to the 11th century kingship," The Romanian Journal for Baltic and Nordic Studies, Vol. 5, No. 2 (2014): 95-104.

- "The Varangian guard and its contribution to the manifestation of the imperial power in Byzantium," The Romanian Journal for Baltic and Nordic Studies, Vol. 7, No. 2 (2015): 7-26.

Matteo Albertini, Balkanalysis.com

- Contribution:

- "Mafia links between the Balkans and Scandinavia. State of affairs," The Romanian Journal for Baltic and Nordic Studies, Vol. 4, No. 2 (2012): 111-150.

Kari Alenius, University of Oulu

- Contributions:

- "Beggars, scammers, discriminated against by the whole of Europe: Romania's Roma in Finnish tabloids, 2008-2011," The Romanian Journal for Baltic and Nordic Studies, Vol. 4, No. 2 (2012): 87-109

- "A Southeastern "other" with diverse challenges. Romania in Finnish schoolbooks," The Romanian Journal for Baltic and Nordic Studies, Vol. 5, No. 1 (2013): 7-26.

- "A typical example of mental region-building? The Balkan area in Finnish schoolbooks from the late 19th 
century to the beginning of the 21st century," The Romanian Journal for Baltic and Nordic Studies, Vol. 5, No. 2 (2013): 25-55.

- "Finnish efforts to promote cultural relations with Romania during the Second World War," The Romanian Journal for Baltic and Nordic Studies, Vol. 5, No. 2 (2014): 169-181.

- "World War II in Baltic and Nordic social media," The Romanian Journal for Baltic and Nordic Studies, Vol. 7, No. 2 (2015): 125-138.

- "The people's expectations of good governance in German-occupied Estonia, 1941-1944," The Romanian Journal for Baltic and Nordic Studies, Vol. 8, No. 2 (2016): 25-46.

Aelita Ambrulevičiute, Vilnius University

- Contribution:

- "Changes in the Vilnius, Kaunas and Grodno provinces peasants' approach to consumption in the second half of the 19th - early 20th centuries," The Romanian Journal for Baltic and Nordic Studies, Vol. 5, No. 2 (2013): 91-118.

Lucia Andrievschi-Bartkiene, Romanian Cultural Association "Dacia"

- Contribution:

- "Multiculturalism versus Nationalism and the role of ethnic minorities in the public life of Lithuania," The Romanian Journal for Baltic and Nordic Studies, Vol. 4, No. 2 (2012): 73-86

Florin Anghel, Ovidius University of Constanta

- Contributions: 
- "Wan light of Lithuania in Bucharest. The sources of a non-declared divorce (1918-1926)," The Romanian Journal for Baltic and Nordic Studies, Vol. 2, Issue 1 (2010): 7-24.

- "Portrait of a necessary Ponto-Baltic alliance: Polish commercial road projects towards the Balkans and the Black Sea, 1919 - 1926," The Romanian Journal for Baltic and Nordic Studies, Vol. 2, Issue 2 (2010): 175-202.

- "Report. The Awarding of Doctor Honoris Causa to H.S. Dr. Vladimir Jarmolenko, The Ambassador of Lithuania to Bucharest," The Romanian Journal for Baltic and Nordic Studies, Vol. 2, Issue 2 (2010): 320-322.

Audronius Ažubalis, Minister of Foreign Affairs of Lithuania

- Contribution:

- "Address by the Minister of Foreign Affairs of Lithuania," The Romanian Journal for Baltic and Nordic Studies, Vol. 2, Issue 1 (2010): 121.

Nerijus Babinskas, Vilnius University

- Contributions:

- “The Concept of Tributalism: A Comparative Analysis of S. Amin's, J. Haldon's and H. H. Stahl's Approaches," The Romanian Journal for Baltic and Nordic Studies, Vol. 1 (2009): 63-83.

- "Henri H. Stahl's conception of historical sociology and the Bucharest School of Sociology," The Romanian Journal for Baltic and Nordic Studies, Vol. 2, Issue 1 (2010): 69-82.

- "Economic challenges in Early Modern Ages and different responses of European margins. Comparative considerations based on historiography: the cases of Polish-Lithuanian Commonwealth and Moldavian Principality," The Romanian Journal for Baltic and Nordic Studies, Vol. 4, No. 2 (2012): 51-62. 
- "Typologies of pre-modern societies beyond feudalism: exploring alternative possibilities and the problem of their applicability in cases of peripheral European societies," The Romanian Journal for Baltic and Nordic Studies, Vol. 10, No. 2 (2018): 9-25.

Gheorghe Barlea, Ovidius University of Constanta \& Valahia University of Targoviste

- Contribution:

- "Leonidas Donskis - an encyclopedic Renaissance-like figure," The Romanian Journal for Baltic and Nordic Studies, Vol. 6, No. 2 (2014): 241-254.

Mehmet Efe Biresselioglu,Izmir University of Economics

- Contribution:

- "Danish Straits versus Turkish Straits: The Potential Impact of Prospective Russian Oil Exports," The Romanian Journal for Baltic and Nordic Studies, Vol. 6, No. 2 (2014): 223-239.

Eva Birzniece, University of Latvia

- Contribution:

- "Construction of Resistance Discourse in Latvian PostSoviet Literature about Deportations and Imprisonments," The Romanian Journal for Baltic and Nordic Studies, Vol. 4, No. 2 (2012): 175-193.

Enikő Molnár Bodrogi, Babes-Bolyai University, Cluj-Napoca

- Contributions:

- "The voice of a "tongueless" periphery," The Romanian Journal for Baltic and Nordic Studies, Vol. 6, No. 1 (2014): 191-205.

- „The Effect of Borders on Identity Building in Minority Life," The Romanian Journal for Baltic and Nordic Studies, Vol. 10, No. 1 (2018): 21-42. 
Dalia Bukeleviciute, Vilnius University

- Contribution:

- "The political and diplomatic relations between Lithuania and Romania (1935-1940)," The Romanian Journal for Baltic and Nordic Studies, Vol. 2, Issue 1 (2010): 25-33.

- "The Little Entente and Romania from the perspective of Lithuanian diplomacy in the 1930s," The Romanian Journal for Baltic and Nordic Studies, Vol. 3, No. 2 (2011): 265-274.

- "European Regional Integration in the Drafting of the Eastern Pact in 1934-1935: Interests of the Baltic Entente and the Little Entente," The Romanian Journal for Baltic and Nordic Studies, Vol. 5, No. 1 (2013): 39-56.

- "Social security assurance for Lithuanian citizens in Latvia in 1919-1939," The Romanian Journal for Baltic and Nordic Studies, Vol. 8, No. 1 (2016): 71-90.

Ion Calafeteanu, Valahia University of Targoviste

- Contribution:

- "Report. The Awarding of Doctor Honoris Causa to H.S. Dr. Vladimir Jarmolenko, The Ambassador of Lithuania to Bucharest," The Romanian Journal for Baltic and Nordic Studies, Vol. 2, Issue 2 (2010): 318-319.

Ioana Cazacu, Al. I. Cuza University of Iasi

- Contributions:

- "The Second Corps of Romanian volunteers in Russia," The Romanian Journal for Baltic and Nordic Studies, Vol. 2, Issue 1 (2010): 111-118.

- "The Nansen Commission and the Romanian prisoners of war's repatriation from the Russian territories," The 
Romanian Journal for Baltic and Nordic Studies, Vol. 3, Issue 1 (2011): 145-159.

Mihai Sebastian Chihaia, Alexandru Ioan Cuza University of Iași

- Contribution:

- "The Baltic Sea and the Black Sea: security challenges and vulnerabilities after the Cold War," The Romanian Journal for Baltic and Nordic Studies, Vol. 7, No. 2 (2015): 153-166.

- "Nordic states contribution to peace and security," The Romanian Journal for Baltic and Nordic Studies, Vol. 8, No. 2 (2016): 73-91.

Vasile Ciobanu, Lucian Blaga University of Sibiu

- Contribution:

- "The Relations Between Transylvanian Saxons and Baltic Germans during the 1920s," The Romanian Journal for Baltic and Nordic Studies, Vol. 1 (2009): 85-98.

Veniamin Ciobanu, A.D. Xenopol Institute of History of the Romanian Academy

- Contributions:

- "Aspects of the Eastern Question found in Swedish diplomatic reports (1813)," The Romanian Journal for Baltic and Nordic Studies, Vol. 2, Issue 2 (2010): 153-174.

- "Data pertaining to the outbreak of the Lithuanian insurrection (25 March 1831), retrieved from Swedish diplomatic sources," The Romanian Journal for Baltic and Nordic Studies, Vol. 3, Issue 1 (2011): 65-86.

- "An attempt to appoint a Swedish vice consul to Bucharest (1834-1835)," The Romanian Journal for Baltic and Nordic Studies, Vol. 4, No. 1 (2012): 35-52.

Alexandru Ciocîltan, "Nicolae Iorga" Institute of History, Romanian Academy 
- Contribution:

- "The identities of the Catholic communities in the 18th century Wallachia," The Romanian Journal for Baltic and Nordic Studies, Vol. 9, Issue 1 (2017): 71-82.

Costel Coroban, Ovidius University of Constanta

- Contributions:

- "Sweden and the Jacobite movement (1715-1718)," The Romanian Journal for Baltic and Nordic Studies, Vol. 2, Issue 2 (2010): 131-152.

- "British reactions to Charles XII's Stay in the Ottoman Empire," The Romanian Journal for Baltic and Nordic Studies, Vol. 3, Issue 1 (2011): 29-63.

- "Elena Dragomir and Silviu Miloiu, Istoria Finlandei," The Romanian Journal for Baltic and Nordic Studies, Vol. 3, No. 2 (2011): 329-330.

- "From the Fringe of the North to the Balkans: The Balkans Viewed by Scottish Medical Women during World War I," The Romanian Journal for Baltic and Nordic Studies, Vol. 4, No. 1 (2012), pp. 53-82.

- "Some linguistic remarks regarding Romanian Viking Studies," The Romanian Journal for Baltic and Nordic Studies, Vol. 5, No. 2 (2013): 119-144.

- "Instances of kingship in Sverris saga," The Romanian Journal for Baltic and Nordic Studies, Vol. 7, No. 2 (2015): 27-42.

- "Power, ideology and piety in high medieval Norway: The King's Mirror," The Romanian Journal for Baltic and Nordic Studies, Vol. 8, No. 1 (2016): 7-20.

- "Representations of political power in medieval Iceland: Íslendingabók," The Romanian Journal for Baltic and Nordic Studies, Vol. 8, No. 2 (2016): 7-24. 
- "A king's luck? A discussion of battle-luck and illfortune in Sverris Saga," The Romanian Journal for Baltic and Nordic Studies, Vol. 9, No. 2 (2017): 7-16.

- "Elated and Traumatized Self(ves) in Autobiographies from the Romanian Front," The Romanian Journal for Baltic and Nordic Studies, Vol. 10, No. 1 (2018): 71-84.

Ion Cucui, Valahia University of Targoviste

- Contribution:

- "Valahia University Rector's Address. The Awarding of Doctor Honoris Causa to H.S. Dr. Vladimir Jarmolenko, The Ambassador of Lithuania to Bucharest," The Romanian Journal for Baltic and Nordic Studies, Vol. 2, Issue 2 (2010): 314.

Muhittin Hakan Demir, Izmir University of Economics

- Contribution:

- "Danish Straits versus Turkish Straits: The Potential Impact of Prospective Russian Oil Exports," The Romanian Journal for Baltic and Nordic Studies, Vol. 6, No. 2 (2014): 223-239.

Ana-Maria Despa, Valahia University of Targoviste

- Contribution:

- "The history of diplomatic relations between Romania and Norway during the interwar period," The Romanian Journal for Baltic and Nordic Studies, Vol. 3, No. 2 (2011): 299-328.

Stefan Donecker,Alfried Krupp Wissenschaftskolleg Greifswald

- Contribution:

- "Wallachian settlers in the Baltic Sea region. A humanist tale of migration and colonization, and its implications for the mental maps of early Modern 
Europe," The Romanian Journal for Baltic and Nordic Studies, Vol. 3, Issue 1 (2011): 9-27.

Sinem Dönmez, Izmir University of Economics

- Contribution:

- "Danish Straits versus Turkish Straits: The Potential Impact of Prospective Russian Oil Exports," The Romanian Journal for Baltic and Nordic Studies, Vol. 6, No. 2 (2014): 223-239.

Leonidas Donskis, ISM University of Management and Economics Vilnius and Kaunas

- Contribution:

- "War and Peace in Eastern Europe: The Ukrainian Lessons," The Romanian Journal for Baltic and Nordic Studies, Vol. 6, No. 2 (2014): 7-26.

- "Identity and memory in Eastern and Central Europe: tracing Czesław Miłosz and Milan Kundera," The Romanian Journal for Baltic and Nordic Studies, Vol. 7, No. 1 (2015): 69-89.

Elena Dragomir, University of Helsinki

- Contributions:

- “To Be or to Become 'European'? 'Westernizing' Narratives in Post-Cold War Finland," The Romanian Journal for Baltic and Nordic Studies, Vol. 1 (2009): 31-50.

- "Development characteristics of interwar European periphery: the cases of Romania and Lithuania's agriculture," The Romanian Journal for Baltic and Nordic Studies, Vol. 2, Issue 1 (2010): 53-68.

- "Lithuanian public opinion and the EU membership," The Romanian Journal for Baltic and Nordic Studies, Vol. 2, Issue 2 (2010): 295-312. 
- "Editorial foreword," The Romanian Journal for Baltic and Nordic Studies, Vol. 6, No. 2 (2014): 5-6.

Roxana-Ema Dreve, Babes-Bolyai University, Cluj-Napoca

- Contributions:

- "Linguistic diversity in The Thief, by Göran Tunström," The Romanian Journal for Baltic and Nordic Studies, Vol. 6, No. 1 (2014): 123-133.

- "Sunne - Göran Tunström's land of peace and beauty," The Romanian Journal for Baltic and Nordic Studies, Vol. 6, No. 2 (2014): 63-67.

- "Norway's political / linguistic / literary policies in the 1830s," The Romanian Journal for Baltic and Nordic Studies, Vol. 8, No. 1 (2016): 45-51.

Gianina Druță, University of Oslo

- Contributions:

- "Hedda Gabler: between territories," The Romanian Journal for Baltic and Nordic Studies, Vol. 8, No. 1 (2016): 53-69.

Kathleen Easlick, University of Manchester

- Contribution:

- "Literary and cultural exchange: translation trends in the Nordic and Baltic countries," The Romanian Journal for Baltic and Nordic Studies, Vol. 6, No. 2 (2014): 77-94.

Marian-Alin Dudoi, Independent Researcher

- Contribution:

- "The Transylvanian issue: Swedish perspectives (19441945)," The Romanian Journal for Baltic and Nordic Studies, Vol. 9, No. 1 (2017): 27-39.

Stefan Ewert, Greifswald University

- Contributions: 
- "Regional higher education co-operation: a research proposal to compare the Baltic Sea and the Black Sea regions," The Romanian Journal for Baltic and Nordic Studies, Vol. 3, No. 2 (2011): 199-224.

- "Baltic Sea regional integration: water protection, university co-operation - and agriculture?," The Romanian Journal for Baltic and Nordic Studies, Vol. 5, No. 2 (2013): 7-24.

Luiza Maria Filimon, National University of Political Studies and Public Administration, Bucharest

- Contributions:

- "An overview of the Copenhagen school's approach to security studies: constructing (in)security through performative power," The Romanian Journal for Baltic and Nordic Studies, Vol. 8, No. 2 (2016): 47-72.

Adél Furu, Babes-Bolyai University, Cluj-Napoca

- Contributions:

- "Maintaining linguistic diversity through multilingual education," The Romanian Journal for Baltic and Nordic Studies, Vol. 6, No. 1 (2014): 97-106.

- "Peace through cultural interaction: the ethnic relations in Finland and Turkey," The Romanian Journal for Baltic and Nordic Studies, Vol. 6, No. 2 (2014): 69-75.

- "Representations of suppressed indigenous cultural memories: the communities of Sami of Finland and Kurdish of Turkey," The Romanian Journal for Baltic and Nordic Studies, Vol. 7, No. 2 (2015): 167-175.

- "Democratic order and ethnic minority rights: the weaknesses of the Finnish and Turkish democracies," The Romanian Journal for Baltic and Nordic Studies, Vol. 8, No. 2 (2016): 93-102. 
- "Recognition of Finland's Independence: a Time of Contemplation," The Romanian Journal for Baltic and Nordic Studies, Vol. 10, No. 1 (2018): 43-51.

Mircea-Cristian Ghenghea, Al.I. Cuza University of Iasi

- Contributions:

- "About Pan-Scandinavianism. Reference points in the 19th century (1815-1864)," The Romanian Journal for Baltic and Nordic Studies, Vol. 6, No. 2 (2014): 127-145.

Alexandru Ghisa, Ministry of Foreign Affairs of Romania

- Contribution:

- "Report. The Awarding of Doctor Honoris Causa to H.S. Dr. Vladimir Jarmolenko, The Ambassador of Lithuania to Bucharest," The Romanian Journal for Baltic and Nordic Studies, Vol. 2, Issue 2 (2010): 319-320.

Inna Gile, Babeș-Bolyai University, Cluj-Napoca

- Contribution:

- "Women in the Latvian War of Independence 1918 1920 in historical memory: nurses' example," The Romanian Journal for Baltic and Nordic Studies, Vol. 7, No. 2 (2015): 177-194.

Oana Raluca Glăvan, Mikolas Romeris University of Vilnius

- Contribution:

- "Multiculturalism versus Nationalism and the role of ethnic minorities in the public life of Lithuania," The Romanian Journal for Baltic and Nordic Studies, Vol. 4, No. 2 (2012): 73-86

\section{Ioana Grecu, Al.I. Cuza University of Iasi}

- Contribution:

- "Norwegian Film Days in Iasi. Alexandru Ioan Cuza University of Iasi, May 27-29, 2012. Interview with Jan 
Erik Holst," The Romanian Journal for Baltic and Nordic Studies, Vol. 4, No. 1 (2012), pp. 105-115.

Marta Grzechnik, University of Greifswald

- Contribution:

- "Intermarium: the Baltic and the Black seas on the Polish mental maps in the interwar period," The Romanian Journal for Baltic and Nordic Studies, Vol. 6, No. 1 (2014): 81-96.

Meri Elisabet Herrala, University of Helsinki

- Contribution:

- "Post-War Friendship Between Neighbors: An outline of Soviet-Finnish Music Exchanges from 1944 towards the collapse of the Soviet Union," The Romanian Journal for Baltic and Nordic Studies, Vol. 6, No. 2 (2014): 27-51.

Kalervo Hovi, University of Turku

- Contribution:

- "Finland's rapprochement to National-Socialist Germany as reaction against Winter War," The Romanian Journal for Baltic and Nordic Studies, Vol. 5, No. 1 (2013): 57-67.

Paweł Jaworski, University of Wroctaw

- Contribution:

- "The beginning of revolution of the "Solidarity" in Poland as seen by the Swedish media (AugustSeptember 1980)," The Romanian Journal for Baltic and Nordic Studies, Vol. 9, No. 1 (2017): 7-26.

Vladimir Jarmolenko, Ambassador Plenipotentiary and Envoy Extraordinary of Lithuania to Bucharest

- Contributions:

- "Foreword," The Romanian Journal for Baltic and Nordic Studies, Vol. 2, Issue 1 (2010): 3-5. 
- "Discourse of reception. The Awarding of Doctor Honoris Causa to H.S. Dr. Vladimir Jarmolenko, The Ambassador of Lithuania to Bucharest," The Romanian Journal for Baltic and Nordic Studies, Vol. 2, Issue 2 (2010): 322-328.

- "20 years from the re-establishment of diplomatic relations between Lithuania and Romania," The Romanian Journal for Baltic and Nordic Studies, Vol. 3, No. 2 (2011): 331-336.

- "Address at the Fourth International Conference on Baltic and Nordic studies in Romania: empire-building and region-building in the Baltic, North and Black Sea areas," The Romanian Journal for Baltic and Nordic Studies, Vol. 5, No. 2 (2013): 201-203.

- "The withdrawal of the Soviet/Russian armed forces and the end of the occupation," The Romanian Journal for Baltic and Nordic Studies, Vol. 8, No. 2 (2016): 103-111

Eriks Jekabsons, University of Latvia, Riga

- Contribution:

- "Pre-World War II Romania from Latvian Perspective: An Envoy's views," The Romanian Journal for Baltic and Nordic Studies, Vol. 3, Issue 1 (2011): 161-181.

Saulius Kaubrys, University of Vilnius

- Contribution:

- "Illegal education of Polish children in Independent Lithuania in the 1930s: circumstances and development trends," Revista Română de Studii Baltice şi Nordice / The Romanian Journal for Baltic and Nordic Studies, Vol. 4, Issue 2 (2012): 63-72.

- "Jewish faction at the Third Seimas of Lithuania in 1926-1927: on the way to the identity crisis," The 
Romanian Journal for Baltic and Nordic Studies, Vol. 5, No. 1 (2013): 27-37.

Dragana Kovacevic, University of Oslo

- Contribution:

- "Young people from Bosnia and Herzegovina in Norway: Migration, Identity and Ethnicity," The Romanian Journal for Baltic and Nordic Studies, Vol. 5, No. 1 (2013): 69-85.

Ramojus Kraujelis, The Lithuanian National Archives and Vilnius University

- Contribution:

- "The status and the future of Baltic States and Romania in the strategy of Western Allies in the early years of the Second World War: a comparative view," The Romanian Journal for Baltic and Nordic Studies, Vol. 2, Issue 1 (2010): 93-109.

Giedrius Kviklys, Vytautas Magnus University of Kaunas

- Contribution:

- "The influence of European Union outer policy initiatives to the EU-Russia relations: cases of Northern Dimension and Black Sea synergy," Revista Română de Studii Baltice şi Nordice / The Romanian Journal for Baltic and Nordic Studies, Vol. 5, Issue 2 (2013): 183-195.

Artur Lakatos, Babes-Bolyai University, Cluj-Napoca

- Contribution:

- "Pal Thonstad Sandvik, Multinationals, Subsidiaries and National Business Systems: the Nickel Industry and Falconbridge Nikkelverk," The Romanian Journal for Baltic and Nordic Studies, Vol. 6, No. 2 (2014): 255-257.

Francesco La Rocca, Central European University, Budapest

- Contribution: 
- "Clashing cultural nationalisms: the 19th-century Danish-German intellectual debate, the Schleswig wars (1848-1864), and some reflections on the cultural roots of National Socialism," The Romanian Journal for Baltic and Nordic Studies, Vol. 7, No. 1 (2015): 105-122.

Kitty Lam, Michigan State University

- Contribution:

- "Forging a Socialist Homeland from Multiple Worlds: North American Finns in Soviet Karelia 1921-1938," The Romanian Journal for Baltic and Nordic Studies, Vol. 2, Issue 2 (2010): 203-224.

Oana Lăculiceanu (Popescu), Grigore Gafencu Research Center for the History of International Relations and Cultural Studies

- Contribution:

- "Danish Perceptions of Interwar Romania," The Romanian Journal for Baltic and Nordic Studies, Vol. 1 (2009): 99-111.

Diana Lătug, Babes-Bolyai University, Cluj-Napoca

- Contributions:

- "The reception of Knut Hamsun in Romania in the period 1919-1926," The Romanian Journal for Baltic and Nordic Studies, Vol. 6, No. 1 (2014): 147-157.

- "Northern Norway in Viking age," The Romanian Journal for Baltic and Nordic Studies, Vol. 9, No. 2 (2017): 17-29.

Crina Leon, Al. I. Cuza University of Iasi

- Contributions:

- "Norwegian Film Days in Iaşi. Alexandru Ioan Cuza University of Iaşi, May 27-29, 2012. Interview with Jan Erik Holst," The Romanian Journal for Baltic and Nordic Studies, Vol. 4, No. 1 (2012), pp. 105-115. 
- "Editorial Foreword," The Romanian Journal for Baltic and Nordic Studies, Vol. 6, No. 1 (2014): 5-6.

- "Dialects in Norway - between tolerance and standardization," The Romanian Journal for Baltic and Nordic Studies, Vol. 6, No. 1 (2014): 107-121.

- "A life dedicated to Romanian language. Interview with Professor Arne Halvorsen," The Romanian Journal for Baltic and Nordic Studies, Vol. 6, No. 1 (2014): 207-211.

- "Knut Hamsun between cultural Germany and political Germany," The Romanian Journal for Baltic and Nordic Studies, Vol. 6, No. 2 (2014): 53-61.

- "Images of 19th century Sweden and Norway in the works Gösta Berling's Saga by Selma Lagerlöf and Children of the Age by Knut Hamsun," The Romanian Journal for Baltic and Nordic Studies, Vol. 7, No. 1 (2015): 91-104.

- "Steinar Lone and the magic of translation," The Romanian Journal for Baltic and Nordic Studies, Vol. 7, No. 1 (2015): 151-158.

- "Editorial Foreword," The Romanian Journal for Baltic and Nordic Studies, Vol. 7, No. 2 (2015): 5-6.

- "Jardar Seim and the history of a Norwegian-Romanian story," The Romanian Journal for Baltic and Nordic Studies, Vol. 8, No. 1 (2016): 91-98.

- "Norwegian studies at "Alexandru Ioan Cuza" University of Iaşi", The Romanian Journal for Baltic and Nordic Studies, Vol. 9, No. 1 (2017): 41-48.

- "Svanhild Naterstad. 'To me Romania is magic!'," The Romanian Journal for Baltic and Nordic Studies, Vol. 9, Issue 1 (2017): 83-90. 
- "An Enemy of the People on the Stage of the Iaşi National Theatre in 2016," The Romanian Journal for Baltic and Nordic Studies, Vol. 10, Issue 1 (2018): 7-20.

Steinar Lone, Freelance translator and writer

- Contribution:

- "The entry of the boyars," The Romanian Journal for Baltic and Nordic Studies, Vol. 7, No. 2 (2015): 43-53.

- "My file," The Romanian Journal for Baltic and Nordic Studies, Vol. 7, No. 2 (2015): 69-84.

Alistair Maeer, Southeastern Oklahoma State University

- Contribution:

- "The Baltic and the birth of a modern English maritime community: the Muscovy Company and nautical cartography, 1553-1665," The Romanian Journal for Baltic and Nordic Studies, Vol. 4, No. 2 (2012): 19-49.

Bogdan Mazuru, State Secretary at the Ministry of Foreign Affairs of Romania

- Contribution:

- "90 years from the establishment of diplomatic relations between Finland and Romania: exhibition of historical documents," The Romanian Journal for Baltic and Nordic Studies, Vol. 3, Issue 1 (2011): 183-193.

Mihaela Mehedinti-Beiean, Babes-Bolyai University of Cluj-Napoca

- Contributions:

- "Relations between Transylvania and the Nordic countries in the 19th century as seen in Romanian periodicals. A quantitative and qualitative analysis," The Romanian Journal for Baltic and Nordic Studies, Vol. 3, Issue 1 (2011): 87-116.

- "Diplomacy as a lifestyle. Nordic and Russian diplomats as links between their countries and the 
Romanian area (17th - 19th centuries)," The Romanian Journal for Baltic and Nordic Studies, Vol. 5, No. 2 (2013): 145-181.

- "Peace or conflict? Past cultural relations between the Nordic countries, Russia and the Romanian area (17th 19th Centuries)," The Romanian Journal for Baltic and Nordic Studies, Vol. 6, No. 2 (2014): 105-126.

- "Political instability and corruption. The Phanariot regime as seen by Russian and Nordic travellers," The Romanian Journal for Baltic and Nordic Studies, Vol. 8, No. 1 (2016): 21-44.

- "From a multi-ethnic empire to a national state: the contribution of Romanian officers in the Habsburg army to the creation of Greater Romania as presented by Transylvanian journalists," The Romanian Journal for Baltic and Nordic Studies, Vol. 10, No. 1 (2018): 53-69.

Olaf Mertelesmann, University of Tartu

- Contributions:

- "The Cost of Transition from Market to Command Economy: The Case of Estonia," The Romanian Journal for Baltic and Nordic Studies, Vol. 1 (2009): 7-30.

- "Leisure in Stalin's Estonia," The Romanian Journal for Baltic and Nordic Studies, Vol. 2, Issue 2 (2010): 225-248.

Dimitris Michalopoulos, Historical Institute for Studies on Eleutherios Veniselos and his Era

- Contribution:

- “'Un singur popor cu două drapele'. The RomanianPolish relations during the interwar period," The Romanian Journal for Baltic and Nordic Studies, Vol. 3, No. 2 (2011): 247-264.

Silviu Miloiu, Valahia University of Targoviste 
- Contributions:

- "Editorial foreword," The Romanian Journal for Baltic and Nordic Studies, Vol. 1 (2009): 3-5.

- "Bogdan Schipor, Politica Marii Britanii la frontiera de vest a Uniunii Sovietice: 1938-1941," The Romanian Journal for Baltic and Nordic Studies, Vol. 1 (2009): 129-130.

- "Nicolae Titulescu's new eastern policy and the upgrading of Romania's diplomatic ties with Lithuania," The Romanian Journal for Baltic and Nordic Studies, Vol. 2, Issue 1 (2010): 35-52.

- "Bogdan Murgescu, Romania si Europa. Acumularea decalajelor economice (1500-2010)," The Romanian Journal for Baltic and Nordic Studies, Vol. 2, Issue 1 (2010): 119120.

- "Editorial foreword," The Romanian Journal for Baltic and Nordic Studies, Vol. 2, Issue 2 (2010): 127-130.

- "From "allies without alliance" to concerted action: Romania and Finland in the aftermath of the Operation Barbarossa (1941)," The Romanian Journal for Baltic and Nordic Studies, Vol. 2, Issue 2 (2010): 249-284.

- "Laudatio. The Awarding of Doctor Honoris Causa to H.S. Dr. Vladimir Jarmolenko, The Ambassador of Lithuania to Bucharest," The Romanian Journal for Baltic and Nordic Studies, Vol. 2, Issue 2 (2010): 314-318.

- "Editor's foreword," The Romanian Journal for Baltic and Nordic Studies, Vol. 3, Issue 1 (2011): 5-8.

- "90 years from the establishment of diplomatic relations between Finland and Romania: exhibition of historical documents," The Romanian Journal for Baltic and Nordic Studies, Vol. 3, Issue 1 (2011): 183-193. 
- "Editor's foreword," The Romanian Journal for Baltic and Nordic Studies, Vol. 4, No. 1 (2012), pp. 5-7.

- $\quad$ "The Third Conference on Baltic and Nordic Studies in Romania, May 2012," The Romanian Journal for Baltic and Nordic Studies, Vol. 4, No. 1 (2012): 213-214.

- "Introduction," The Romanian Journal for Baltic and Nordic Studies, Vol. 5, No. 1 (2013): 5-6

- "Introduction," The Romanian Journal for Baltic and Nordic Studies, Vol. 5, No. 2 (2013): 5-6.

- "Editorial foreword," The Romanian Journal for Baltic and Nordic Studies, Vol. 6, No. 2 (2014): 5-6.

- "When the West is far away: Romanian attempts to withdraw from World War II (1943-1944), Finnish views," The Romanian Journal for Baltic and Nordic Studies, Vol. 6, No. 2 (2014): 183-205.

- "Editorial foreword," The Romanian Journal for Baltic and Nordic Studies, Vol. 7, No. 1 (2015): 5-6.

- "CoolPeace: Syllabi of disciplines", The Romanian Journal for Baltic and Nordic Studies, Vol. 7, No. 1 (2015): 7-67.

- "Editorial foreword," The Romanian Journal for Baltic and Nordic Studies, Vol. 8, No. 1 (2016): 5-6.

- "Editorial foreword," The Romanian Journal for Baltic and Nordic Studies, Vol. 8, No. 2 (2016): 5-6.

- "Editorial foreword," The Romanian Journal for Baltic and Nordic Studies, Vol. 9, No. 1 (2017): 5-6.

- „Baltic studies in Romania: sources, beginnings and perspectives," The Romanian Journal for Baltic and Nordic Studies, Vol. 9, No. 1 (2017): 49-70.

- "Editorial foreword," The Romanian Journal for Baltic and Nordic Studies, Vol. 9, No. 2 (2017): 5-6. 
- "Editorial foreword," The Romanian Journal for Baltic and Nordic Studies, Vol. 10, No. 1 (2018): 5-6.

- "Editorial foreword," The Romanian Journal for Baltic and Nordic Studies, Vol. 10, No. 2 (2018): 5-6.

- "On the Pathway to Independence: The Congress of the Representatives of the Lithuanian Military Officers of the Romanian Front (1917)," The Romanian Journal for Baltic and Nordic Studies, Vol. 10, No. 2 (2018): 67-90.

Irmeli Mustonen, Ambassador of Republic of Finland to Romania

- Contribution:

- "90 years from the establishment of diplomatic relations between Finland and Romania: exhibition of historical documents," The Romanian Journal for Baltic and Nordic Studies, Vol. 3, Issue 1 (2011): 183-193.

Ádám Németh, University of Pécs, Institute of Geography

- Contribution:

- "Alteration of the ethnic diversity and ethnic segregation index in Latvia during the first and second independence periods," The Romanian Journal for Baltic and Nordic Studies, Vol. 4, No. 1 (2012), pp. 9-33.

Michael North, University of Greifswald

- Contributions:

- "Reinventing the Baltic Sea Region: From the Hansa to the Eu-Strategy of 2009," The Romanian Journal for Baltic and Nordic Studies, Vol. 4, No. 2 (2012): 5-17.

- "The Sea as Site of Memory: The Danish Sound and the Dardanelles in Comparison," The Romanian Journal for Baltic and Nordic Studies, Vol. 6, No. 1 (2014): 65-79.

Nicoleta Carmen Olteanu, University of Bucharest

- Contributions: 
- "How did 22/7 shape the political rhetoric on immigration and integration in Norway?," The Romanian Journal for Baltic and Nordic Studies, Vol. 6, No. 2 (2014): 207-221.

Raluca Petruş, Babes-Bolyai University, Cluj-Napoca

- Contribution:

- "Cultural accommodation in learning and teaching the Norwegian language in Cluj-Napoca," The Romanian Journal for Baltic and Nordic Studies, Vol. 6, No. 1 (2014): 159-174.

Emanuel Plopeanu, Ovidius University of Constanta

- Contribution:

- "War, diplomacy and media: the British-Soviet Treaty of May 26, 1942 in Swedish press commentaries," The Romanian Journal for Baltic and Nordic Studies, Vol. 2, Issue 2 (2010): 285-294.

Arvydas Pocius, Ambassador of the Republic of Lithuania in Romania

- Contribution:

- "The Romanian-Finnish Cultural Relations: History, Trends, Bibliography," The Romanian Journal for Baltic and Nordic Studies, Vol. 10, No. 1 (2018): 85-86.

Alexandru Popescu, Ministry of Foreign Affairs of Romania

- Contribution:

- "The Romanian-Finnish Cultural Relations: History, Trends, Bibliography," The Romanian Journal for Baltic and Nordic Studies, Vol. 1 (2009): 113-128.

Giuseppe Raudino, Hanze University of Applied Sciences, Groningen

- Contribution:

- "Questions of transnational cinema: the Baltic case from culture to branding," The Romanian Journal for Baltic and Nordic Studies, Vol. 7, No. 2 (2015): 103-124. 
Raluca-Daniela Răduț, Babes-Bolyai University of Cluj-Napoca

- Contribution:

- "An overview of the Scandinavian poetry translated in Romanian culture," Revista Română de Studii Baltice şi Nordice / The Romanian Journal for Baltic and Nordic Studies, Vol. 6, Issue 1 (2014): 135-146.

Klaus Richter, Technische Universität Berlin, Centre for Research on Anti-Semitism

- Contribution:

- "Kišinev or Linkuva? Rumors and threats against Jews In Lithuania in 1903," The Romanian Journal for Baltic and Nordic Studies, Vol. 3, Issue 1 (2011): 117-130.

Bogdan Schipor, A.D. Xenopol Institute of History of the Romanian Academy

- Contributions:

- "The Polish-Lithuanian Crisis of March 1938. Some Romanian and Western reactions," The Romanian Journal for Baltic and Nordic Studies, Vol. 2, Issue 1 (2010): 83-92.

- "The German Invasion of Norway, April-June 1940: Romanian Echoes," The Romanian Journal for Baltic and Nordic Studies, Vol. 10, No. 2 (2018): 91-107.

Jardar Seim, The Norwegian Historical Association

- Contribution:

- "Approaching the past: a tangled interplay of memory, political choices and historical science," The Romanian Journal for Baltic and Nordic Studies, Vol. 7, No. 2 (2015): 55-68.

Rūta Šermukšnytè, Vilnius University, Faculty of History

- Contribution:

- "Between truth and memory: images in Lithuanian historical documentaries in post-communist 
transformation period," The Romanian Journal for Baltic and Nordic Studies, Vol. 7, No. 2 (2015): 85-101.

Paulina Siegień, University of Gdansk

- Contribution:

- "Reading the facades. Architexture of Kaliningrad city," The Romanian Journal for Baltic and Nordic Studies, Vol. 7, No. 2 (2015): 55-68.

Vasilica Sîrbu, University of Oslo

- Contribution:

- "The Nobel Peace Prize from a Romanian perspective the interwar period," The Romanian Journal for Baltic and Nordic Studies, Vol. 3, No. 2 (2011): 275-298.

- "Romanians and the Nobel Prizes for Science and Literature," The Romanian Journal for Baltic and Nordic Studies, Vol. 4, No. 1 (2012), pp. 83-104.

Guntis Šolks, University of Latvia, Faculty of Geography and Earth Sciences

- Contribution:

- "Alteration of the ethnic diversity and ethnic segregation index in Latvia during the first and second independence periods," The Romanian Journal for Baltic and Nordic Studies, Vol. 4, No. 1 (2012), pp. 9-33.

Cezar Stanciu, Valahia University of Targoviste

- Contributions:

- "Scandinavian Perspectives. Overcoming the Cold War Pressures in Romania's Policy towards Northern Europe," The Romanian Journal for Baltic and Nordic Studies, Vol. 1 (2009): 51-62.

- "The common denominator. Romania and the Nordic countries, 1966-1969," The Romanian Journal for Baltic and Nordic Studies, Vol. 4, No. 2 (2012): 195-212. 
Andrius Švarplys, Vytautas Magnus University of Kaunas

- Contribution:

- "What the membership has taught? National identity construction in Lithuanian public discourse after accession to the European Union," The Romanian Journal for Baltic and Nordic Studies, Vol. 4, No. 2 (2012): 151-173.

Sanda Tomescu-Baciu, Babes-Bolyai University, Cluj-Napoca

- Contribution:

- "Cultural accommodation in learning and teaching the Norwegian language in Cluj-Napoca," The Romanian Journal for Baltic and Nordic Studies, Vol. 6, No. 1 (2014): 159-174.

Claudiu-Lucian Topor, Al. I. Cuza University of Iasi

- Contribution:

- "German policy and the diplomatic agenda of Romanian neutrality (1914-1916). The prospects for an alliance with Sweden," The Romanian Journal for Baltic and Nordic Studies, Vol. 3, Issue 1 (2011): 131-144.

Ulla Väistö, The Embassy of Finland in Romania

- Contribution:

- "Address at the Fourth International Conference on Baltic and Nordic studies in Romania: empire-building and region-building in the Baltic, North and Black Sea areas," The Romanian Journal for Baltic and Nordic Studies, Vol. 5, No. 2 (2013): 197-200.

Vesa Vares, University of Turku

- Contribution:

- "'Never satisfactory, according to the Finnish standards'. From optimism and interest to disappointment and disillusion: Finnish views on the nations in Eastern Central Europe between the word 
wars," The Romanian Journal for Baltic and Nordic Studies, Vol. 3, No. 2 (2011): 225-246.

Ildikó P. Varga, Babes-Bolyai University of Cluj-Napoca

- Contribution:

- "Towards an international university. A professorship at The Franz Joseph University (Cluj-Napoca) in 1901," Revista Română de Studii Baltice şi Nordice / The Romanian Journal for Baltic and Nordic Studies, Vol. 6, Issue 1 (2014): pp. 175-189.

Cristina Vişovan, Babes-Bolyai University of Cluj-Napoca

- Contribution:

- "Old Norse gods in contemporary Norwegian novels," Revista Română de Studii Baltice şi Nordice / The Romanian Journal for Baltic and Nordic Studies, Vol. 9, Issue 2 (2017): pp. 31-50.

Adrian Vitalaru, Al. I. Cuza University of Iasi

- Contribution:

- "Romanian diplomats in the Scandinavian countries (1916-1947)," The Romanian Journal for Baltic and Nordic Studies, Vol. 6, No. 2 (2014): 147-167.

Darius Žiemelis, Lithuanian Institute of History

- Contributions:

- "The socio-economic history of Lithuania from the 16th to the 19th century (until 1861) from the perspective of economic development concepts," The Romanian Journal for Baltic and Nordic Studies, Vol. 5, No. 2 (2013): 57-90.

- "The problem of the application of the term second serfdom in the history of Central Eastern Europe: the case of Lithuanian economy in the 16th-19th (until 1861)," The Romanian Journal for Baltic and Nordic Studies, Vol. 7, No. 1 (2015): 123-149. 
- "The comparative analysis of Lithuanian manorial-serf economy and hacienda economic system of Latin America in the context of capitalist world system: from the second half of the 18th to the second half of the 19th centuries," The Romanian Journal for Baltic and Nordic Studies, Vol. 10, No. 2 (2018): 27-65. 